\title{
A world unsafe for democracy? China and the shaping of global order
}

\author{
Rosemary Foot
}

Abstract: Much recent analysis of a resurgent and influential China has focused on the country's present and likely future role in shaping global order. A significant part of this deliberation has been built around two propositions: whether Beijing's intentions are predominantly defensive - it seeks only a 'world safe for autocracy' - or are offensive - it seeks to diminish the space that is needed for liberal democracies to thrive. This debate is in danger of becoming far too polarised. For those taking the 'defensive China' route, it is important to reflect that Beijing seeks not just passive protection from harm, but also active approval of its politico-economic system, and that activism may have ideational and material consequences. For those painting a more offensive posture on China's part, there are also examples of Beijing having moderated its position when there is resistance, and having accepted the need to compromise to gain external validation. Any investigation of China's capacity to shape global order requires considerably higher levels of attention not only to the determination of Chinese strategic intentions, but also to how those with whom China interacts are responding to its policy positions.

Keywords: China and global order, autocracy, democracy, politico-economic models, China's strategic intentions, Belt and Road Initiative.

Note on the author: Professor Rosemary Foot is a Senior Research Fellow in the Department of Politics and International Relations at the University of Oxford, a Research Associate of the University's China Centre, and an Emeritus Fellow of St Antony's College, Oxford. Recent publications include China, the UN, and Human Protection: Beliefs, Power, Image (2020); 'China's Rise and US Hegemony: Renegotiating Hegemonic Order in East Asia', International Politics (2020, https://doi.org/10.1057/s41311-019-00189-5); and (with Amy King) 'China's World View in the Xi Jinping Era: Where do Japan, Russia and the USA fit?', British Journal of Politics and International Relations (2021, https://doi.org/10.1177/1369148120914467). She was elected a Fellow of the British Academy in 1996. 
Recent policy and academic analyses of the consequences for global order of a resurgent and influential China have focused on the country's strategic goals. A significant part of this deliberation has been built around two propositions: whether Beijing's intentions are predominantly defensive - it seeks only a 'world safe for autocracy' - or are offensive - it seeks to diminish the space that is needed for liberal democracies to thrive. Some are fearful that a world dominated by autocratic states would compromise the very viability of remaining liberal democracies. It may even bring about a world reminiscent of the 1930s. However, others depict a Beijing that is supportive of authoritarian polities because it fears Western-promoted regime change inside China itself, using the internet as one tool in the armoury to remove the Communist Party from power. The 'colour revolutions' in Eurasia and the eruption of the 'Arab Spring' sounded alarm bells for the Chinese Communist leadership, reinforcing its sense that it had to do more to prevent the advancement of liberal values and what it depicted as US-sponsored destabilisations of non-democratic regimes (for examples of this range of views, see Christensen 2021; Doshi 2021; Heath et al. 2021; Economy 2021; Rolland 2020; Friedberg 2020; Chen Weiss 2019).

In light of these opposing arguments, it has become paramount to find ways of deepening our understanding of the scope of Chinese ambition, but also regularly to investigate the extent to which Beijing is realising, adapting, or changing its ambition. Attentiveness to the policy process is as important as uncovering the overall objectives of Beijing's policy, not least because the translation of power into actual policy influence is notoriously difficult. Determining China's intentions is a necessary undertaking, but so too is a realistic appraisal of its likely success in the realisation of those intentions, together with the extent to which Beijing is willing to modify its positions as it deals with the consequences of becoming a far more active presence in global politics.

\section{China remaking the world?}

Those whose perspectives embrace the idea of a China remaking the world can point to a variety of statements and policy areas where that ambition is manifest and is designed to undermine levels of confidence in alternative political models. President $\mathrm{Xi}$ exhorts Chinese officials not only to take a leading role in the reform of global governance, but also actively to formulate global rules. He, his Foreign Minister, and other leading officials frequently encourage others to benefit from 'Chinese wisdom', to recognise that China has blazed 'a new trail for other developing countries to achieve modernisation', and has offered a 'new option for other countries and nations who want to speed up their development' (Xi 2017). In a 2021 White Paper on poverty 
alleviation, the State Council boldly stated that China's successes offer an 'approach to solving the problem of modern national governance and creating brighter prospects for social progress' (State Council 2021). Xi reinforced these sentiments in his July 2021 speech celebrating 100 years of the Chinese Communist Party. In it he noted that China had 'created a new model for human advancement' (Xinhua 2021). At a South-South Human Rights Forum in Beijing in 2017, a Chinese Vice Foreign Minister made an especially striking claim, asserting that the meeting had enhanced China's soft power 'by translating domestic governance philosophies into international consensus' (Ministry of Foreign Affairs 2017).

China's contemporary discourse reflects its belief that it has a good story to tell, that its narrative of success contrasts markedly with the failures of the liberaldemocratic model, and it rather than the West is setting the global agenda and the standards associated with that agenda. As State Councillor Yang Jiechi put it in November 2017, the Western-led global governance system is outdated, has 'malfunctioned' and is 'beyond redemption' (Yang quoted in Heath 2018). In support of this argument, Chinese officials and scholars point to a wide range of examples, including the West's costly interventionist policies in the Middle East, and the weaknesses of the neo-liberal economic model as shown in the global financial crisis of 2008.

President Biden has taken note and added to a sense of unease associated with China's apparently increased confidence. In a series of US administration statements and documents, the world has been depicted as being at 'an inflection point' and 'in the midst of an historic and fundamental debate' about the nature of world order one where there exist powerful forces arguing that autocracy rather than democracy is the way to bring about better outcomes for our changing and contested world order (White House 2021). Defenders of democratic practices appear to be under siege, not least because the United States itself has recently provided ample evidence of a constant need for democracies to police and re-evaluate their own standards of behaviour. A worrying trend is that, according to some measures, the number of states attracting the label democratic is now less than 10 per cent, whereas a third or more of the world's population resides in an authoritarian state.

For those preoccupied with the expansive nature of Beijing's goals, not only does China's discourse suggest an important change in ambition, but so too does its behaviour. Beijing is said to be actively promoting its politico-economic model in Africa, but also in all parts of the developing world where it has initiated the so-called Belt and Road infrastructure projects associated with the Xi Jinping era. As a further boost to the promotion of its economic model overseas, it has been buying up local media so that it can advance messages that offer a favourable depiction of China's policies. Beijing also invites Party and Governmental officials to China to learn about such topics as the management of public opinion, the alleviation of poverty, and why 
the promotion of development should be seen as a foundational human right (Sun 2016; Foot 2020).

In international organisations, and especially in those where new norms are being created, as in the field of emerging technologies, it is moving to align international standards with its domestic preferences, and to promote the uptake of its own platforms. Dominance in advanced technological areas is the aim for commercial, political, and military reasons. Beijing also is working to establish principles and global norms that reduce the role of international adjudication in determining outcomes, instead prioritising sovereign state control in various areas of policy. In the case of technological governance, for example, its promotion of the notion of cyber sovereignty translates into tight governmental control over the internet, the localisation of data, and policing of internet gateways (Moynihan \& Patel 2021).

Even in well-established international organisations, such as the United Nations, it is seeking more actively to shape its practices and in particular to return it to a body focused on a more traditional Westphalian state-based vision of world order, not one that prioritises the protection of the individual (Foot 2020). To boost its influence at the UN, Beijing has competed fiercely to become the executive head of several Specialized Agencies, has sought out international civil servant positions in the Secretariat, and has expanded the numbers of Chinese nationals on UN internships, outstripping those of all other countries (Lynch 2020).

What does all this activity imply? For this group of analysts it means gradually aligning the world more closely with Chinese values, norms, and policy preferences. Beijing, in this understanding, is acting in effect as a multiplier in the steady advancement of the prospects of autocratic states, adding to the sense that political liberalism will no longer remain a major force in world politics. Authoritarian states will feel more secure and enabled in their anti-democratic practices. Semi-authoritarian states will succumb to the temptations of control and repression, Beijing having altered the incentives for adhering to liberal democratic norms. Liberal democracies will feel embattled, faced both with the urgent necessity of repurposing their domestic polities and the difficulties of maintaining open societies in the presence of malign forces.

\section{A narrower vision?}

However, not all are convinced. Those sceptical of the argument that China is in an existential struggle with democratic ways of life emphasise that Beijing is actually in search of external legitimation to shore up its one-Party rule at home. Beijing's political elites share the conviction that the regime will never be secure or attain great power status in an international order based predominantly on liberal principles. 
That sense of insecurity is higher in an era where it has become a global actor with global interests and with close relationships that are important to maintain in the face of increased external scrutiny of its behaviour. Thus, within that international order it seeks praise for what it has achieved and to quash all criticism of its failings. To legitimate at home, it needs to provide evidence of legitimacy abroad and hence to reinforce the norms of non-interference in internal affairs, and respect for civilisational difference rather than an assumption that particular ways of life are inherently superior to others. Beijing wants to undercut the idea that there are universal values, instead to substitute the argument that it should be accepted that countries at different stages of development will adopt policies that are determined by that developmental stage.

Moreover, so this argument runs, unlike Maoist China, Beijing appears ready to coexist with many states of different ideological hues provided their governments do not attack China's own governance arrangements or threaten its national unity. Although there is some political exploitation of open, democratic societies, there is a lack of hard evidence that it is working diligently to train opposition forces in the methods required to overthrow such governments. China certainly has moved closer to autocratic governments like Iran, Russia, and Venezuela, but the degree of closeness is contained: evidence is scarce that it is constructing formal alliance arrangements that require reciprocal and tangible support at times of military conflict. And while there are many official Chinese statements suggesting that developing countries would be wise to adopt policies that resemble a China model, there is also constant reference to the unique 'Chinese characteristics' associated with the dimensions of that model - an assumption at Chinese elite levels of the country's exceptionalism rooted in its culture, historical experience, and socialist system (Chen 2019; Christensen 2021).

Important also to this defensive case is that much of what contemporary China is doing in the world today is not so different in its broad outlines from what it has done for many decades. The main caveat is that where once its claim to fame rested on the success of its anti-imperialist struggle, it now relies on tangible evidence of its economic progress to impress its partners. Studies of China-Africa relations show that African leaders have travelled to China on multiple occasions from Maoist times onwards to learn about party development, how to create an army loyal to the party, and how to use developmental state ideas to control the commanding heights of the economy (Verhoeven 2020). Chinese communist ideas about rural development, the importance of building infrastructure, and the need to deliver primary health care all found their way into the continent, particularly in the early years of decolonisation. Whether that African 'learning' experience has led to significant change on the ground is far more complex to assess.

But if Chinese ideas were made available to African elites, so too were the ideas of others. China had competitors in Africa, with Asian states such as the Republic of 
Korea, Singapore, and Vietnam being invited to offer their perspectives. The Korean Development Institute (KDI), founded in 1971, for example, has been of particular interest to Ethiopia because of a desire to understand South Korea's success in sustaining fast growth rates using private investment under the guidance of the state. Even at a time of high Chinese influence in the country in 2013, the KDI established a knowledge-sharing programme with almost all ministries represented in Ethiopia's federal government (Verhoeven 2020: 12).

China also does not always have the playing field to itself when it tries to promote its advanced 21st-century technologies, including in Asia. Companies based in the West have been shown to be exporting facial recognition technology and network cameras to a variety of Asian countries including China as well as India, the Philippines, and Singapore.

In addition, what might be rather too readily categorised as evidence of China's direct influence may in fact derive from similarity of purpose. For example, of the over 200 instances of shutdowns of the internet across the world that took place in 2019, well over half took place in Asian countries (Moynihan \& Patel 2021). This suggests a prevalent and underlying suspicion of the destabilising societal effects of such technologies and a more general distrust of non-state organisations. Vietnam, while it may have modelled its cyber security law on the Chinese regulatory framework, would undoubtedly have adopted similar tactics with or without that Chinese example. More reflective of current circumstances is the finding that governments in Asia are discovering their own motives for and ways of controlling online activity.

These points suggest that many countries, to varying degrees, share ideas about forms of governance with China, but they may not always acquiesce to Beijing's requirements. Even in asymmetrical relationships, states have agency if they choose to exercise it. They are not all supine followers that have been subjected to Beijing's transactional diplomacy. Instead, in Maoist and post-Maoist times ideas and practices have been engaged selectively or not at all in response to local circumstances. We see this with respect to the Belt and Road Initiative (BRI) where evidence has mounted that recipients of Chinese largesse are renegotiating their investment loans, or cancelling contracts altogether (Patey 2021). Sometimes this has come because of a change in domestic political circumstances inside the recipient state, a firmer intent to assess the viability of projects, or growing doubts about the benefits to be derived from a close relationship with Beijing. Vital too, however, is the presence of viable alternative provision of economic, political and social resources. 


\section{Evaluating influence, evaluating evidence}

Adjudication between the two positions outlined here requires closer examination of Chinese discourse, together with more detailed exploration of its behaviour with individual governments and international organisations. But, crucially, it also requires investigation of the preferences and normative standpoints of those same target states and institutions.

With respect to Chinese statements and documents reflecting an official Chinese world view, for example, their interpretation requires serious thought about who is the intended audience, how significant is the particular individual or bureaucracy promoting the message, and the extent to which statements on similar topics and directed either at domestic or external audiences are seriously in tension or together reinforce a policy line.

To deepen understanding of China's external relations, we need to explore the extent to which alignments emerge because of a convergence in normative positioning between China and its interlocutors. It is not unusual, for example, to find states in the international system that, like China, find reassurance in the norm of the legal sovereign equality of nations and the associated idea of non-interference in internal affairs. Many would also like to see economic development given a higher policy priority in world politics. Moreover, anti-democratic trends in a number of Western societies may have reinforced the legitimacy of normative consensus with China.

In the absence of such a normative alignment, we need to assess the conditions under which China uses persuasive argument, economic largesse, or a variety of forms of coercion to generate outcomes that the target state would have preferred to resist. Of particular concern would be cases where the domestic polity of the recipient of Chinese pressure or persuasion is altered in significant ways.

Similarly, China's potential export of the 'China model' needs to be scrutinised more deeply. What form does the training activity that China provides or the conference participation that it offers take? Who attends such activities and do they hold positions of real influence in the participating countries? Specialists on the countries or regions so targeted are vital to engage in the intellectual conversation, since they are best placed to provide evidence of whether such participation has led to the adoption of new policies in the target countries or has recognisably moved the political orientation of those polities.

With respect to extant international organisations or in cases where new multilateral organisations have been established, we need to assess whether China has actually begun to exercise structural power: that is, has it been able to set agendas, to reinterpret or replace norms associated with a well-established institution, or to establish the normative frameworks of new institutions? Is there, instead, resistance to Beijing's 
positions, or a modification of its standpoints as China is co-opted into adopting a more globally consensual position? And if so, which particular issues are most subject to these forms of resistance and a resultant search for consensus?

There is, then, considerable fluidity in the system that requires further probing before the debate elaborated in this commentary can advance much further. The debate is in danger of becoming too polarised, particularly at a time when many Western governments perceive themselves as facing a crisis of governance. More obviously, there appears to be some kind of continuum in play here. For those taking the 'defensive China' route, it is important to reflect that Beijing seeks not just passive protection from harm, but also active approval of its politico-economic system, and that activism may have ideational and material consequences. Chinese ambition may grow as new opportunities arise. For those painting a more offensive posture on China's part, there are also examples of Beijing having moderated its position when there is resistance, and having accepted the need to compromise to gain external validation. This is so with respect to the BRI, given pressure on China to offer greater transparency, improve its lending practices, and adopt sustainable development solutions. Where there is this continuum in play, then there needs to be constant attention to where China is sitting on that continuum at particular moments and over which particular issues.

Any investigation of China's capacity to shape global order also requires considerably higher levels of attention not only to the determination of Chinese intentions, but also how those with whom China interacts are responding to its policy positions. It has long been recognised that the translation of influence into desired outcomes is elusive even for the most powerful of actors. This has become even more the case in a world where power has diffused, and where there are now multiple stakeholders involved in resolving the existential challenges that we all face. Those challenges have made the development model that China currently promotes - one built on nationally-determined policies and experiences - essentially anachronistic in a world where shared fate issues, such as climate change, pose a direct threat to the survival of humanity.

\section{Acknowledgements}

My thanks to Professors Todd Hall and Marc Williams for valuable comments on an earlier version of this article. 


\section{References}

Chen Weiss, J. (2019), 'A World Safe for Autocracy? China's Rise and the Future of Global Politics,' Foreign Affairs, 98(July/August): 92-102.

Christensen, T.J. (2021), 'There will Not be a New Cold War: The Limits of US-Chinese Competition,' Foreign Affairs, 101(March/April).

Doshi, R. (2021), The Long Game: China's Grand Strategy to Displace American Order (New York, Oxford University Press).

Economy, E. (2021), 'An Order Aligned with Chinese Values' (Lowy Institute). https://interactives.lowyinstitute.org/features/china-rules-based-order/articles/chinese-order/

Foot, R. (2020), China, the UN, and Human Protection: Beliefs, Power, Image (Oxford, Oxford University Press).

Friedberg, A.L. (2020), 'An Answer to Aggression', Foreign Affairs, 99(September/October): 150-64.

Heath, T.R. (2018), 'China Prepares for an International Order after U.S. Leadership', The RAND Blog. https://www.rand.org/blog/2018/08/china-prepares-for-an-international-order-after-us.html

Heath, T.R., Grossman, D. \& Clark, A. (2021), China's Quest for Global Primacy (Santa Monica CA, Rand Corporation).

Lynch, C. (2020, 14 August), 'China’s Soft-Power Grab', Foreign Policy. https://foreignpolicy. com/2020/08/14/china-soft-power-united-nations-hong-kong-crackdown/.

Ministry of Foreign Affairs, China (2017, 10 December), 'Writing a New Chapter of International Human Rights Exchanges and Cooperation' (Embassy of the People's Republic of China in the Republic of Lithuania). https://www.fmprc.gov.cn/ce/celt/eng/xwdt/t1519583.htm

Moynihan, H \& Patel, C. (2021, 17 March), 'Restrictions on online freedom of expression in China: the domestic, regional and international implications of China's policies and practices', Research Paper (London, Chatham House). https://www.chathamhouse.org/2021/03/ restrictions-online-freedom-expression-china

Patey, L. (2021), How China Loses: the Pushback Against Chinese Global Ambitions (New York, Oxford University Press).

Rolland, N. (ed.) (2020), An Emerging China-Centric Order: China's Vision for a New World Order in Practice (Seattle WA, National Bureau of Asian Research).

State Council Information Office of the People's Republic of China (2021, April), 'Poverty Alleviation: China's Experience and Contribution'.

http://www.xinhuanet.com/english/download/2021-4-6/FullText.pdf

Sun, Y. (2016), 'Political Party Training: China's Ideological Push in Africa?' (Washington DC, Brookings Institution), 5 July, at https://www.brookings.edu/blog/africa-in-focus/2016/07/05/ political-party-training-chinas-ideological-push-in-africa/

Verhoeven, H. (2020), 'The Party and the Gun: African Liberation, Asian Comrades, and Socialist Political Technologies', Third World Quarterly. https://doi.org/10.1080/01436597.2020.1791069.

White House (2021, March), 'Interim National Security Strategic Guidance' (Washington DC, The White House). www.whitehouse.gov/wp-content/uploads/2021/03/NSC-1v2.pdf

$\mathrm{Xi}$, J. (2017, 18 October), 'Secure a decisive victory in building a moderately prosperous society in all respects and strive for the great success of socialism with Chinese characteristics for a new era', Speech delivered at the 19th National Congress of the Communist Party of China. http://www. xinhuanet.com/english/download/Xi_Jinping's_report_at_19th_CPC_National_Congress.pdf

Xinhua (2021, 1 July), 'Chinese President Xi Jinping delivers his speech in Beijing on Thursday'. http://www.xinhuanet.com/english/special/2021-07/01/c_1310038244.htm 
To cite the article: Rosemary Foot (2021), 'A world unsafe for democracy? China and the shaping of global order', Journal of the British Academy, 9: 213-222.

DOI https://doi.org/10.5871/jba/009.213

Journal of the British Academy (ISSN 2052-7217) is published by

The British Academy, 10-11 Carlton House Terrace, London, SW1Y 5AH

www.thebritishacademy.ac.uk 